\title{
On Culture Teaching in Business English Translation Classroom
}

\author{
Qiuyun OU \\ School of Foreign Languages, Hubei University of Education, Wuhan 430205, China \\ 553678283@qq.com
}

\begin{abstract}
There is a hypothesis that the raising of learner's cultural awareness and infiltration of cultural contents in translation teaching may have a good effect. This paper describes a research done with this purpose. The findings of the research, which is about a questionnaire and its feedback from Business English Major Students within a provincial university, focuses on the students' comprehension and attitudes towards culture study and translation. Through the analysis to the data collected, it proves the positive effect of culture teaching to BE translation classroom. The paper suggests that it is necessary for the teachers of translation class to integrate translation skills with strategies of cultural awareness training.

Index Terms - culture teaching, business English translation, direct cultural input
\end{abstract}

\section{Introduction}

It is assumed that, among most translation teachers, a good translation teaching is a harmonious integration of translation skills with linguistic and intercultural knowledge and competence. However, whether it is of the same reaction among the learners is still unknown. Therefore, in translation classroom, such assumption is worth investigating.

The following part is about the findings and analysis to an investigation which is done with a purpose of improving translation teaching. The initial step of the research is done with a form of questionnaire. Questions are designed to help the teachers of translation to understand more on students' cultural awareness and their willingness of taking effort of studying culture in Business English translation classroom to test whether such awareness has an influence to classroom teaching.

The target being tested is sophomore and junior students of Business English major within a university in Hubei Province, China. Through investigation, the assumption of the research is proved, that the enhancement of students' cross-cultural awareness and the implanting of cultural contents are essential to translation teaching. This finding may help to prove the effectiveness of introducing culture-related knowledge in translation classroom. The papers also suggests that the strategies on raising students' cultural awareness and careful designed cultural contents in translation classroom, such as business culture, may help to solve the current problems in practical teaching.

\section{On Studies and Teaching of Culture Teaching in Translation Classroom}

There are issues concerned before the teacher's introducing culture notion in translation classroom. The first is how a culture of target language can affect teachers' or students' beliefs and classroom practices. "Students need to learn the cultural ways in which L2 speakers communicate" [1]. Teaching culture is of priority to translation class. As to the form of a special slot, such as setting a culture corner of culture spot in the lesson, or each lesson seeking to contain a cultural awareness skill that students develop through the textbook and associated materials is really a challenge to the teachers. ${ }^{[2]}$ Teachers are sometimes puzzled as to teaching the skills of identifying culturally significant information and developing cultural skills[2]. There is no solid foundation to the effectiveness of the teachers' presenting culture-related lectures to tell the students what they need to know, even if doing so is always considered to be a routine job for most language teachers[3].

Another concern is the teaching methodology. The teachers' usually apply task-based learning and discovery techniques to help the students learn for themselves for the sake of encouraging the latter's autonomy. However, there is no certain answer for such assumption. There are doubts on appropriate methods for teachers who are not native speakers (such as Chinese teachers who are less familiar with the English culture) or to teaching culture and its real effect. Teachers need a clear picture as to how much he/she knows about the students' understanding on culture and an idea on useful information to the students. The following questionnaire was designed with the purpose of finding out causes and effects.

As to the necessity of teaching culture in English-Chinese translation, it can be concluded that with English now being used globally across diverse cultures as lingua franca, English educators will not only need to be more culturally and linguistically aware the significance of teaching culture, but they are also able to design course-related materials with an international and multicultural focus. [4] Therefore, educating students to make use of English as a lingua franca also means developing their intercultural capacity and sensitivity. In Chinese environment, students should be allowed to know different cultural knowledge. To achieve better quality in intercultural communication and translation, it is essential to minimize misunderstandings when communicating within international, cross-cultural and multicultural settings.

\section{On the Research and Questionnaire}

Business English Major Students are chosen as the target of the research for they are not only the learners of languages, 
but they are likely the future employees to companies. The present situation of the class is beyond satisfaction in that some students complain that their only study on the translation skills won't help in having accurate target language. There must be some other reasons for causing students' low quality of translation --- insufficient language comprehension, improper mastery of culture or other factors. Years of teaching translating practice proves that with only translation skills in teaching make the teacher unable to fulfill the task of guiding the students to learn what underneath the language. Therefore, what a translation classroom can do is of prior importance.

To motivate students, the teacher usually tries mentioning cultural contents, such as anecdotes of some celebrities, legendary stories of famous scenic spots, etc. However, these fragmental elements are less effective. Therefore, there is an urgent need for the teacher to find out the students' real concern about culture before a possible solution to the issues concerned. In non-native speaking environment like China, the contact with authentic materials is rare that most students depend a lot on the information given by the teachers or the textbooks, which, however, are second-hand information.

Inspired by experimental study of Byram[5], an investigation is designed to find out more about cultural study in translation classroom teaching. The first stage of the investigation is in the form of a questionnaire, which is handed out to test students' understanding on significance of culture and their effort on the study. Students' comments and suggestions to culture in translation class are also included. 194 participants--- sophomore and junior students of Business English major give respond to the questionnaire.

The questionnaire consists of 11 questions, the design of which is inspired by an investigation which is done by Weiwei Shen to university students in Zhejiang Province of China[6]. Thus, the validity and reliability of the questions are not mentioned in this paper. The detailed information on it can be classified as four types:

\begin{tabular}{|l|l|}
\hline Type 1 (Q 1,2,8) & $\begin{array}{l}\text { on students' cultural awareness in learning foreign } \\
\text { language and translation }\end{array}$ \\
\hline $\begin{array}{l}\text { Type 2( Q3, 4, } \\
5,7,9,10,11)\end{array}$ & $\begin{array}{l}\text { on students' attitude and time-spending on culture and } \\
\text { translation study }\end{array}$ \\
\hline Type 3 (Q6) & on students' autonomous study on culture \\
\hline Type 4 (Q12) & $\begin{array}{l}\text { on comments and suggestions to translation classroom } \\
\text { teaching }\end{array}$ \\
\hline
\end{tabular}

(The data of Type 4 is not included in the present paper.)

The target of the research is to investigate translation learners' needs and comprehension to culture, for they are the end-users of the course of translation and their ability of BE translation is supposed to be the final result of culture study. The investigation may accumulate information to assist the researcher to find out whether the deliberately-designed tailor-made culture-related information/knowledge has a strong impact on translation classroom teaching.

The findings of the investigation are listed below:

\section{Category 1: on students' knowledge of cultural awareness}

When asked about the concern of the students for culture knowledge during English learning, over a half of them $(51 \%)$ respond that they know some knowledge of culture. 50 students say that they know quite a lot of culture knowledge, 22 of them are quite confident that they know very much of it. The students' confidence is possibly related with the Chinese domestic situation after the opening policy in China, when there are more and more opportunities and resources for them to know about the outside world. The participants agree that culture knowledge plays an important role in English study. In the classroom teaching, such cultural knowledge, when introduced by teachers, can be sometimes clearly absorbed, $72.6 \%$ students hold this idea. 18 students respond that they cannot understand the cultural knowledge unless the teacher reminds them. It suggests that the help of teacher's instructions on certain cultural knowledge may be beneficial to the students. However, there is a lot for the teacher to consider in teaching, especially the contents included in the translation class, and the systematic and scientific ways of design.

Here comes another question that whose culture should be mentioned in the class. As a matter of fact, translation involves in both target and source language and their culture. English learners in China are strongly influenced by American and British culture. So, when the question on "how much do you know about the culture in the western countries" is asked, all students answer that they know a little or some knowledge, however, mostly of the knowledge of cultures are about the previous-mentioned two nations. Chinese culture cannot be ignored.

\section{Category 2: on students' attitude and time-spending on culture and translation study}

One of the most effective ways of acquiring culture is by reading books written by the native speakers. To Business English learners, business knowledge and commercial culture are of strong desire. The investigation shows that students learned a lot through this way (38\% of students read "a few" of books or other materials on cultures in the western countries, and $58.5 \%$ read some). However, it is interesting to find out that $81.4 \%$ of the students mainly depend on teacher's introductions, seven students learn about culture only under the teacher's requirement. Seldom learn culture autonomously ( $6 \%$ only). Considering the dependence of the students to the teacher, there is a big task for the teacher to evaluate on the contents of knowledge to satisfy all the needs of the students. It can be inferred that even $66.4 \%$ students believe that they spend 1-3 hours learning culture things outside classroom, and they still have the habit of relying on teachers, even if it's outside the classroom. That is partly because Chinese students who are influenced a lot by Confucius idea respect the teacher, and they usually listen to and accept whatever the teacher tells them. Thus, it is demanding job for the teacher to choose proper materials, since the students expect the teacher to introduce culture to them. The question of this categories shows that the students 
expect a time from one hour to three in the class to study materials on culture. There is suggestion that culture-related information be given in accordance with the development of the course. However, considering the time allotment for translation class (i.e. 1.5 hours a week, 16 weeks a semester), the time for background knowledge is limited considering that there are sections for translation theories and skills.

The teacher's assumption is that cultural learning may be helpful to correct and more accurate translation. When asked about the question to the students, their choice matches with the teacher's expectation (94 think "much" help, 41 "some", which take up $69.6 \%$ of the participants). Good understanding of culture may have strong affect on translation.

To be more specific, the question about translation and culture is asked about students' handling the relation between training translation skills and learning culture. The following table shows students' response: Students' concern on learning translation skill and culture are showed in the following table:

\begin{tabular}{|l|c|c|}
\hline Students' attitude & Students' choice & percentage \\
\hline Only concern skill training & 8 & $4 \%$ \\
\hline Only concern culture learning & 4 & $2 \%$ \\
\hline Lay equal stress on the two & 54 & $27.8 \%$ \\
\hline $\begin{array}{l}\text { Skill training first, culture learning } \\
\text { second }\end{array}$ & 96 & $49.5 \%$ \\
\hline $\begin{array}{l}\text { Culture learning first, skill training } \\
\text { second }\end{array}$ & 36 & $18.6 \%$ \\
\hline
\end{tabular}

In practical translation classroom, the skills of translation are like tools for walking, while culture is like the guide showing direction. Thus it is of concern to the teacher to consider the time and effort on each aspect. A combination of both skills and culture knowledge might be a good choice for the teachers.

Another concern of the students is mistranslations or wrong translation in their works, especially the ones with culture-loaded words and expressions. The following shows what the students consider on the reasons for wrong or improper translation.

Students' understanding on causes of mistranslation can be categorized as follows:

\begin{tabular}{|l|c|c|}
\hline Reasons for wrong and mistranslation & Students' choice & Percentage \\
\hline Don't know some words & 62 & $32 \%$ \\
\hline Can't analyze sentence structure & 46 & $23.7 \%$ \\
\hline Don't understand the context & 36 & $18.6 \%$ \\
\hline Don't know some culture specifics & 85 & $43.8 \%$ \\
\hline Others: poor Chinese & 13 & $6.7 \%$ \\
\hline
\end{tabular}

Still, the findings match with the teacher's expectation, that in practical classroom teaching, even though students understand the literal meanings of words, they cannot absolutely get the proper translation, most of the reasons of such kind of inappropriate expressions are the result of culture-prominent issues.
It can be drawn by the findings that student's comments and expectations are helpful in improving effectiveness of translation classroom. Business English translation class expects more about knowledge of culture and business. In the questionnaire, Category 4 is designed for this purpose. Student's answers vary: Some expect that the teacher gives them more chance to practice and use what they have learned in and out of class, that they expect the teacher to tell them the way to accumulate translation material. Some expect teachers' explanation and analysis in more specific ways to analyze on Chinese idioms, or that more emphasis will be laid on practices rather than the explanation and analysis on works. Cultural background introduction is necessary as well that half of the comments are related with culture, to further emphasizes the importance of culture in translation teaching and studying, which is the next step to further research. Actually, it is hard to satisfy all the needs of the students; however, it is still worth trying to have tailor-made materials.

\section{Implications to Business English b Translation Teaching}

The pilot research shows that although students have clear understanding on the significance of studying culture in the process of translation, there is still insufficient awareness to culture. Thus, from an optimistic perspective, there is still improvement for translation teacher to try.

\section{A. An integration of translation theories and skills with} culture knowledge

The interaction and communications with languages is materialized through translation. The importance of the latter is further highlighted when taking information exchange and globalization into consideration. Translation is complex, in that many factors play to influence the quality. The translation classroom teaching may infiltrate culture knowledge throughout the process of learning. When teacher delivers lectures, he/she may come across materials with cultural factors, i.e. knowledge with people's ideas, senses of value, attitude and appreciation. The teachers need strategies in translation class:

a. Comparative and contrastive study on culture-loaded words and expressions

In translating class, words and expressions are the initial and smallest units, among them the most difficult for learners to deal with are culture-loaded words (words and expressions with cultural connotation, like idiom, phrases, etc. They are rich in specific pragmatic meanings to the native speakers as to the barrier to translator). Once the teacher makes comparative or contrastive study on these expressions, he/she may help students to comprehend more on the cultural associations. Thus, it may release the obstacles in students' translation process.

\section{b. Direct culture input}

It's common method in FLT in which the teacher directly introduces or explains cultural background information in the translation materials to lower the risks of misunderstanding. To Chinese learners who have the habit of dependent to teacher, this way may help them better. Though, to some extent, to encourage more on learners' autonomy, students 
may be asked to look for this cultural knowledge through various resources.

\section{c. Creating a cultural environment}

The globalization makes it possible for both learners and teachers to acquire knowledge about culture. What the teacher might do is to tell the students to distinguish various kinds of culture knowledge by application of authentic materials. However, there is still limitation in acquiring such materials. Usually the teacher can probably guide the students by creating a cultural environment related to translation classroom. A good suggestion to the teacher is to supply the students with authentic in-class materials, which may come from the internet or published paper media, like novels, magazines and newspaper report, etc. In spite of the fact that it is difficult for the teacher, it's worth trying to give a real picture to the students to know exactly the real things people in the west encounter. The environment of culture also refers to courses design, where there exist as much as possible the culture-related courses in the syllabus. Plenty of extra curriculum activities, whether they are out of the teacher's requirement of organized by students themselves, are part of culture environment as well, for language learners need more time in studying culture. Some effective extra curriculum activities, such as watching TV series, participating in intercultural communication, campus language exchange activities, and so on are helpful.

\section{B. Dialectical and comparative study on ways of thinking}

Besides trying to deal with the issue of what is culture, the teacher needs to show latest research on some other aspects of language, such as mode of thinking, etc. Since language is the vehicle of human thoughts, its reflection is in the form of culture, a further study on similarities and differences will be beneficiary. To start with is different ways of thinking in China and that of the west. Chinese people pay more attention to global thinking and there's usually a roundabout way in expressing, while the westerners are more direct in telling. This will absolutely cause a various way in expressing as the form of language, which will be a barrier for translator. Contrastive way on studying the differences of thinking mode may remind the students in their practical translation.

\section{Conclusion}

The research itself is just a pilot investigation on students' attitude and comments on culture study of themselves and study on it inspire teaching culture in translation classroom. An estimated effect of such investigation is that, after one year's study on translation classroom, with the teacher's deliberately-designed input of the culture, the quality of translation works for the learners are to improve. This is ideal for translation classroom teaching. It cannot be denied that there are barriers in practical teaching. Regardless of the bottlenecks, such as the teacher's limitation on range of knowledge, reliability to the translation textbooks, strict requirement of syllabus designs, and some on, some helpful suggestions are given to those unsolvable problems of vital importance and significance to translation. Therefore, it leaves room for further discussion on effectiveness of cultural awareness skills in helping with the improvement of quality of translation.

\section{References}

[1] M. Byram \& M. Fleming: Intercultural Experience and Education. Clevedon: Multilingual Matters, 2002

[2] Tomalin, Barry: Making culture happen in the English language classroom, 8 October, 2008 - 15:48

[3] University of Kragujevac, Integrating culture and language teaching in TEYL, conference proceeding No. 16, http://www.pefja.kg.ac.rs/preuzimanje/Tempus/ZBORNIK_TEYL_Co nferece_Proceedings.pdf

[4] Nault, Derrick: Going Global: Rethinking Culture Teaching in ELT Contexts, Language, Culture and Curriculum, Volume 19, Issue 3, 2006, 314-328

[5] Byram, M., \& Esarte-Sarries, V.: Investigating cultural studies in foreign language teaching. Clevedon: Multilingual Matters, 1991

[6] Shen, Wei-Wei: Exploring L2 Learners' Cultural Awareness: Explaining Chinese (L1) Cultural Keywords in English, http://www.hltmag.co.uk/apr09/mart01.htm 